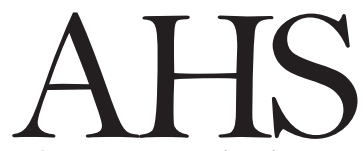

Advances in Horticultural Science
OPEN ACCESS

(*) Corresponding author: marufsau@hotmail.com

Citation:

TAUFIQUE T., NISHIZAWA T., ROY T.S., MEIKO K., CHAKRABORTY R., MOSTOFA M., NARA K., 2021 Histological and physiological changes of potato starch derived from seed and TPS (True Potato Seed) grown tubers under different cold storage duration. - Adv. Hort. Sci., 35(4): 371-381

Copyright:

(C) 2021 Taufique T., Nishizawa T., Roy T.S., Meiko K., Chakraborty R., Mostofa M., Nara K. This is an open access, peer reviewed article published by Firenze University Press

(http://www.fupress.net/index.php/ahs/) and distributed under the terms of the Creative Commons Attribution License, which permits unrestricted use, distribution, and reproduction in any medium, provided the original author and source are credited.

Data Availability Statement:

All relevant data are within the paper and its Supporting Information files.

Competing Interests:

The authors declare no competing interests.

Received for publication 25 July 2021

Accepted for publication 2 December 2021

\section{Histological and physiological changes of potato starch derived from seed and TPS (True Potato Seed) grown tubers under different cold storage duration}

T. Taufique ${ }^{1,2}$, T. Nishizawa ${ }^{1}$, T.S. Roy ${ }^{2}$, K. Meiko ${ }^{1}$, R. Chakraborty ${ }^{2}$, M. Mostofa $^{3(*)}$, K. Nara $^{1}$

1 Department of Bioproduction, Faculty of Agriculture, Yamagata University, 1-23 Wakaba Machi, Tsuruoka 997-8555, Yamagata, Japan.

2 Department of Agronomy, Faculty of Agriculture, Sher-e-Bangla Agricultural University, Dhaka 1207, Bangladesh.

3 Institute of Seed Technology, Sher-e-Bangla Agricultural University, Dhaka 1207, Bangladesh.

Key words: Amylopectin, cold storage period, potato, starch granule size, sugar content.

Abstract: Starch granules in potato tubers exist with varying sizes and size distribution in nature. In this study, both the tubers of seed potato ('Lady Rosetta') and true potato seed (TPS) ('BARI TPS-1') varieties were stored at $5^{\circ} \mathrm{C}$ for 0 to 4 months, and the changes in the starch break down were analyzed physiologically and histologically to investigate how cold storage affects the starch break down. Although the starch content of both varieties reduced during cold storage, the reduction of starch content in 'BARI TPS-1' was higher than that of 'Lady Rosetta'. However, both volume and ovality (length:width) of starch granule did not change significantly throughout the storage period irrespective of variety, suggesting a non-uniform breakdown of starch granules. Scanning Electron Microscope (SEM) images of starch granule showed non-uniformed deformation and enlarged cavity or hole along the storage period, which indicated that starch breakdown occurred at a specific part of starch granule rather than peripherally and penetration would be deeper in 'BARI TPS1 ' than that of 'Lady Rosetta'. However, there was no significant change in granule size distribution in spite of rapid degradation of amylopectin percentage in 'BARI TPS-1' than that of 'Lady Rosetta', suggesting more susceptibility of 'BARI TPS-1' to starch degrading enzyme and higher enzymatic action would cause deeper penetration in 'BARI TPS-1' than that of 'Lady Rosetta'.

\section{Introduction}

Potato (Solanum tuberosum L.) crop is usually cultivated by planting seed tubers which are genetically identical clones. On the other hand, True Potato Seed (TPS) is the actual botanical potato seed produced by the potato plant. Potato production from seed tuber derived 
from TPS (seedling tuber) is emerging as a promising alternative of using seed tuber due to the advantages of less disease transmission, physiological maturity until planting season, cheap storage cost, and many choices of varieties (Pangaribuan, 1994). As potato tuber comes to maturity, starch-rich perimedullary region forms the major portion of the tuber (Gupta and Kaur, 2000), and potato granules are synthesized and stored as roughly spherical shapes in amyloplasts (Naeem et al., 1997; Fajardo et al., 2013) As the tuber matures, new starch granules are also synthesized in newly produced amyloplasts. There is usually a large granule size distribution within individual tubers in terms of percentages of small, medium, and large granules (Singh et al., 2016). The size of small and large granules ranged from 0.6 to $6 \mu \mathrm{m}$ and from 10 to $100 \mu \mathrm{m}$ in potato starch, respectively (Wang et al., 2018), consisting of smooth-surfaced, oval and irregular shape (Singh et al., 2003). Singh et al. (2008) reported small starch granules of 1 to $10 \mu \mathrm{m}$, medium granules of 11 to $30 \mu \mathrm{m}$ and larger granules of $>30 \mu \mathrm{m}$ in diameter in four different New Zealand potato cultivars.

Cold storage of potato tuber results in disintegration and disappearance of the amyloplast membranes around the starch granules, which bring in contact with the degradative enzymes such as $\alpha$-and $\beta$ - amylases and their substrates (Badenhuizen, 1965; O'donoghue et al., 1995). Thus, prolonged storage of potato tuber at low temperatures can result in starch degradation and conversion of starch into reducing sugar (Zhang et al., 2014). When potato tubers (Solanum tuberosum) are stored at temperatures below $9-10^{\circ} \mathrm{C}$, the accumulation of sucrose and reducing sugars glucose and fructose occurred because of 'low-temperature sweetening' (LTS) (Pinhero et al., 2007). The rate of starch degradation and sugar accumulation depends largely on cultivar and storage temperatures (Kazami et al., 2000). Starch content was found to be decreased about 2 times after storage at $0-2^{\circ} \mathrm{C}$ for 8 weeks in both seed potato and TPS potato tuber by (Karim et al., 2008). A decrease of starch content was also reported after 60-105 days of storage at $4^{\circ} \mathrm{C}$ in several Indian potato varieties (Yamdeu et al., 2015). On the other hand, Biemelt et al. (2000) reported that the starch content did not alter throughout the storage period. The starch degradative enzyme not only affects the starch content in cold storage also starch granule. The enzymatic susceptibility of starch granules has been studied by various authors (Franco et al., 1988;
Srichuwong et al., 2005; Adejumo et al., 2013). Differences in the enzymatic attack or susceptibilities of starches depend on many factors such as starch source, granule size, extension of association between starch components, rate of amylose and amylopectin, crystalline structure, particle size, surface porosity, type of enzyme (Hoover and Zhou, 2003; Kong et al., 2003; Li et al., 2004; Tester et al., 2006). A shift to lower granule size distribution has been reported in raw starches of different potato varieties after in-vitro enzymatic hydrolysis (Kimura and Robyt, 1995). Cold Induced Sweetening (CIS) susceptible cultivars can cause smaller starch granules when stored for 4 or 12 weeks at $4^{\circ} \mathrm{C}$ rather than CIS resistant cultivars, which does not change until 24 weeks (Barichello et al., 1990). Based on the previous observations, it was hypothesized that when potato tubers are stored at low temperature conditions, starch granule content and size change in relation to starch degradation. Starch granules may change randomly or according to size because several studies showed that the starch granule size is an important factor for influencing the digestibility of raw starch by amylase (Noda et al., 2008). Ezekiel et al. (2010) observed that the number of small granules decreased, and the number of large granules increased in potato after cold storage. Granule size and surface area affect the hydrolysis rate of starch by amylase, large granules with higher diameter have smaller surface area than small granules with lower diameter and therefore larger granules digested more slowly (Tester et al., 2006; Kasemwong et al., 2008; Noda et al., 2008). Because of the susceptibility to hydrolytic enzyme attack, deformation like external corrosion, pits or endo-erosion occurred on the starch granule (Planchot et al., 1995).

Even though starch granules change in relation to starch degradation, it is unclear whether and how these happen in case of 'seed tuber' and TPS tuber at the same storage condition. So, the aim of this experiment was to study whether the starch degradation occurs similarly or differently in seed potato and TPS tuber; and how the starch degradation affects the starch granule deformation morphologically in both tubers.

\section{Materials and Methods}

\section{Plant material}

In October 2015, each of 50 potato tubers of 
'BARI TPS-1' (TPS) and 'Lady Rosetta' (seed potato) were obtained from Bangladesh. Volume, size, and weight of all the tubers were measured and were stored at $5^{\circ} \mathrm{C}$ for 0 to 4 months in a refrigerator at the laboratory of the Department of Agronomy, Faculty of Agriculture, Sher-e-Bangla Agricultural University, Bangladesh. The 'Lady Rosetta' variety is one of the widely cultivated commercial seed potato in Bangladesh, which is also used as processed potato. On the other hand, 'BARI TPS-1' is one of the wellcultivated 'True Potato Seed' variety, which is cultivated from true seed in first year and from the tuberlets from second year. Both of the tuber was collected and cultivated in the experimental plot of Sher-eBangla Agricultural University with integrated crop management. Ten tubers per each variety were taken out monthly from the refrigerator, the skin was peeled off and the tubers were grated using a grater of about $45 \mathrm{~mm}$ diameter. Half of the grated sample was then blended and washed with desalted water, and filtered through filter paper. This step was repeated 3 times and then filtrated and dried in sunlight under shaded condition for few days when the environmental temperature was around $34^{\circ} \mathrm{C}$. This unheated samples were prepared for starch granule observation using SEM (Scanning Electron Microscope). The other half of the grated sample was added to $80 \% \mathrm{MeOH}(100 \mathrm{~mL})$ and heated at $80^{\circ} \mathrm{C}$ for 30 minutes. The supernatant was decanted, and the residue was extracted by $80 \% \mathrm{MeOH}(100 \mathrm{~mL})$. This step was repeated for 3 times in total and then washed by pure acetone. Then, it was heated and dried on a hot plate at 50 to $70^{\circ} \mathrm{C}$ only in the daytime and stored at the ambient temperature at night. It took 3 days to dry completely and was weighed repetitively up to constant dry weight. The completely dry sample was cooled to the ambient temperature, stored in a freezer at $-20^{\circ} \mathrm{C}$. This $80 \%$ $\mathrm{MeOH}(100 \mathrm{~mL})$ extracted samples were used for sugar and starch analysis. The chemical analysis was done at the laboratory of the Department of Bioproduction, Faculty of Agriculture, Yamagata University, Japan.

\section{Soluble sugar content}

A $0.2 \mathrm{~g}$ of dry powder from each cultivar was taken into a test tube, then $9 \mathrm{~mL}$ of $80 \% \mathrm{MeOH}$ was added, and it was heated at $80^{\circ} \mathrm{C}$ for $30 \mathrm{~min}$. The extract was centrifuged at $3000 \mathrm{rpm}$ using a centrifuge (KS-500, KUBOTA, and Tokyo) for $10 \mathrm{~min}$, and the supernatant was decanted. This extraction procedure was repeated for 3 times, and the combined supernatant was made up to $50 \mathrm{~mL}$ volume with $80 \%$ $\mathrm{MeOH}$. Reducing sugar content in $0.5 \mathrm{~mL}$ of the solution was measured by Somogyi Nelson method (Nelson, 1944), and the $0.5 \mathrm{~mL}$ of the solution was added by 2 units of invertase ( $\mathrm{pH} \mathrm{4.5,} \mathrm{Kanto,} \mathrm{Kagaku,}$ Tokyo) and hydrolyzed at $50^{\circ} \mathrm{C}$ for $30 \mathrm{~min}$. Sucrose content in the solution was also measured using the same technique as reducing sugar. Copper reagent and nelson reagent were used to prepare a standard solution of glucose. Absorbance was measured at $660 \mathrm{~nm}$, and a standard curve was prepared to calculate reducing sugar. Non-reducing sugar was measured from hydrolytic degradation of sucrose, and absorbance was measured at $660 \mathrm{~nm}$.

Abs obtained from the analysis of reducing sugar was denoted by ABS 1 ... (1)

Abs obtained from the analysis of non-reducing sugar was denoted by ABS 2 ... (2)

Concentration of non-reducing sugar was calculated from $=\{$ Abs (2) - Abs (1) $\} \times 0.95 \ldots$ (3)

Concentration of total soluble sugar was calculated from $=(1)+(3)$

These steps were repeated for 5 times for each cultivars and for each storage sample.

\section{Starch content}

The insoluble solid from the $80 \% \mathrm{MeOH}$ extract was added with $1.5 \mathrm{~mL}$ of distilled water and heated at $100^{\circ} \mathrm{C}$ for $1 \mathrm{hr}$. Starch in the pellet was hydrolyzed using amyloglucosidase (Yakult) at $55^{\circ} \mathrm{C}$ for $3 \mathrm{hrs}$ then neutralized by $0.1 \% \mathrm{NaOH}$ solution. Starch content was also measured in $0.5 \mathrm{ml}$ of the solution using the same technique of sugar analysis and Glucose Oxidase method. Glucose standard curve was prepared to measure starch content. Absorbance was measured at $660 \mathrm{~nm}$ for Somogyi Nelson Method and at $500 \mathrm{~nm}$ for Glucose Oxidase method and was repeated for 5 times for each cultivars and for each storage sample.

Abs obtained from the analysis of starch was denoted by Abs ... (4)

Starch content was calculated from $=$ Abs $4 \times 0.9$.

\section{Histological analysis of starch granule}

Starch powders were scattered on an adhesive carbon tape and were fixed with $2 \%$ osmium tetroxide $\left(\mathrm{OsO}_{4}\right)$ and successively washed with $50 \mathrm{mM}$ cacodylate buffer and ultrapure water. The dried samples were coated by Pt using each sample slides by Pt ion coater (JFC-1200, JEOL, Tokyo), and then observed under SEM Scanning Electron Microscope (SEM, TM3000, Hitachi, Tokyo). The length and width 
of the starch granules were measured by using Motic Image Plus 2.0 software from SEM images. The length and width ratio of starch granule was measured as the ratio of length:width.

Starch granule was regarded as an ellipsoid, and the volume of starch granule was measured of each axis of the ellipse. For histogram analysis (volume and length/width ratio) 10 SEM image of $x 500$ magnification and $200 \mu \mathrm{m}$ across from each treatment were chosen and 5 granules from each image were measured randomly (total 500 starch granules).

\section{Amylose percentage determination}

Amylose content was measured using an assay kit (Megazyme, Amylose/Amylopectin Assay Kit, Ireland) according to the procedure outlined by the manufacturer. Percentage of amylose was directly calculated following the specific Megazyme equation based on the measured absorbance values, no additional standard curve or equation was generated for this study. Amylopectin content was calculated by $100 \%$ difference of the amylose content (Aristizábal et al., 2007). This step was repeated for 5 times for each cultivar and for each consecutive storage sample.

\section{Statistical analysis}

Data were subjected to analysis of variance and the difference between cultivars was compared with t-test using SPSS software.

\section{Results}

\section{Soluble sugar content}

In 'BARI TPS-1' tubers, reducing sugar content reached the highest value $(57.80 \mathrm{mg} / \mathrm{g}$ DW) after 1 month of storage then decreased rapidly thereafter. Reducing sugar of 'Lady Rosetta' showed the same tendency but the highest value after 1 month of storage $(25.86 \mathrm{mg} / \mathrm{g}$ dry weight) was less than half of that of 'BARI TPS-1' and decreased gradually thereafter (Fig. 1). Therefore, reducing sugar content of 'BARI TPS-1' was significantly higher than that of 'Lady Rosetta' during 1 to 3 months of storage. Although, sucrose content also showed the highest value after 1 month of storage, the value decreased rapidly thereafter. The decline of 'BARI TPS-1' was slower than that of 'Lady Rosetta', resulting in a significant difference between the two varieties during 2 to 3 months of storage (Fig. 1). Changes in total sugar content were similar to that of sucrose content and significantly higher content was observed also in
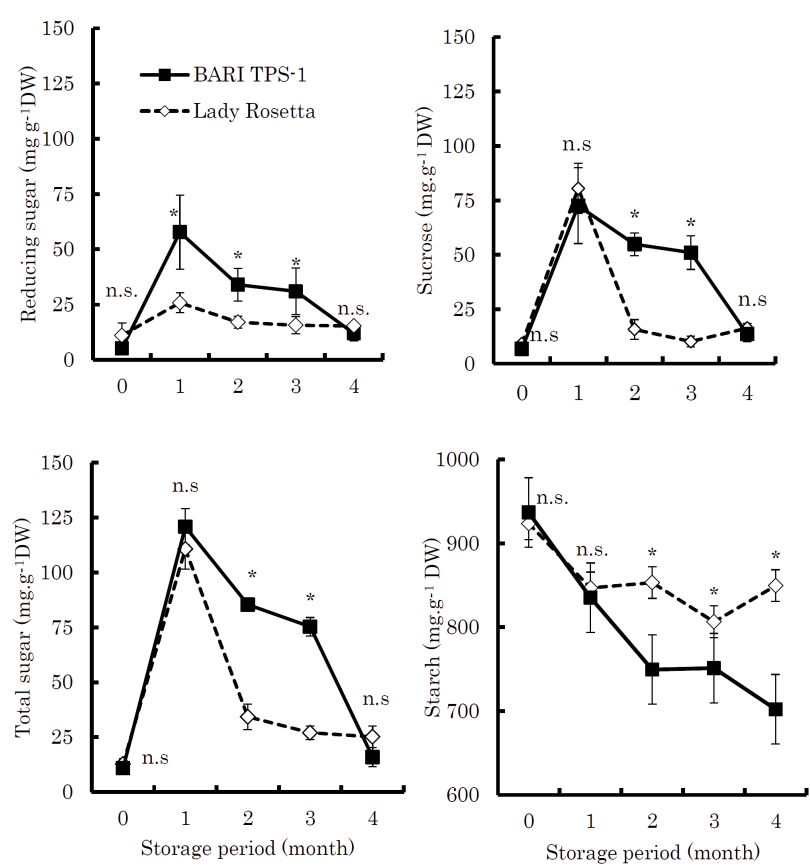

Fig. 1 - Changes in soluble sugar and starch contents of two potato cultivars as affected by different storage period ( $\mathrm{n}$ $=5 \pm \mathrm{SE}$ ). ${ }^{*}$ shows significant difference and n.s. shows non-significant different at $\mathrm{P}<0.05$ by student's t-test.

'BARI TPS-1' during 2 to 3 months of storage (Fig. 1).

\section{Starch content}

Although starch content of both potato varieties decreased continuously throughout the storage period, starch content of 'BARI TPS-1' decreased more rapidly than that of 'Lady Rosetta' variety, resulting in a significant difference from 2 to 4 months of storage (Fig. 1). It is noticeable from figure 1 that decreasing level of starch content was on par with the increasing reducing sugar content, where 'BARI TPS-1' showed rapid starch degradation with higher reducing sugar content after 2 to 4 months of storage than that of 'Lady Rosetta'. Similarly increase in sucrose level of 'BARI TPS-1' after 1 month of storage paralleled with the decreased level of starch content, resulting significant differences between two varieties.

\section{Starch granule sizes}

Starch granule length, width, length:width ratio and volume did not change apparently throughout the storage period. Though 'Lady Rosetta' had a tendency to have slightly higher values in length, width and volume, there was no significant difference between the both 'BARI TPS-1' and 'Lady Rosetta' (Fig. 2).

Histogram was shown for starch granule volume 

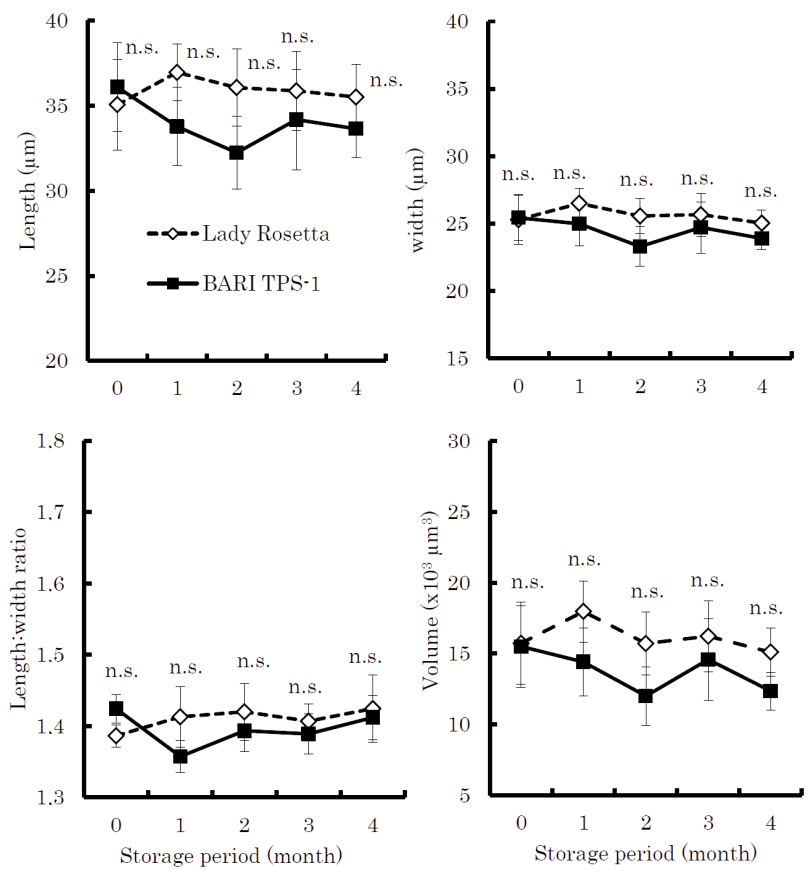

Fig. 2 - Changes in the sizes of starch granule derived from two potato cultivars as affected by different storage period for $(n=10 \pm S E)$. * shows significant difference and n.s. shows non-significant difference at $\mathrm{P}<0.05$ by student's $\mathrm{t}$ test.

and ovality (length:width) within the range of (0.5 to 81.5) $\times 10^{3} \mu \mathrm{m}^{3}$ and (1.05 to 2.22 ) respectively (Fig. 3 and 4). The highest frequency was observed at (7.6 13.5) $\times 10^{3} \mu \mathrm{m}^{3}$ and (1.19 and 1.31) for volume and ovality, respectively and there was no considerable differences between the two cultivars. Moreover, no apparent change also occurred during storage period.

\section{Starch granule morphology}

Both 'BARI TPS 1' and 'Lady Rosetta' tubers showed normal and smooth starch granule surface at 0 -month storage (Fig. 5). Starch granules of both tubers changed after storage condition. Pit and hole like structures were observed after 1 month storage in both varieties. After $2^{\text {nd }}, 3^{\text {rd }}$ and $4^{\text {th }}$ month storages prominent depression or cavity was observed in both potato cultivars. However, both potato tubers showed a similar pattern of deformation.

\section{Amylopectin percentage}

Although the percentage of amylopectin in both potato varieties decreased continuously throughout the storage period, Amylopectin of 'BARI TPS-1' decreased more rapidly than that of 'Lady Rosetta' variety, resulting in a significant difference from 2 and 4 months of storage (Fig. 6). Although 'Lady Rosetta' variety had slightly higher percentage than TPS after 3 months of storage, there was no significant difference between them.

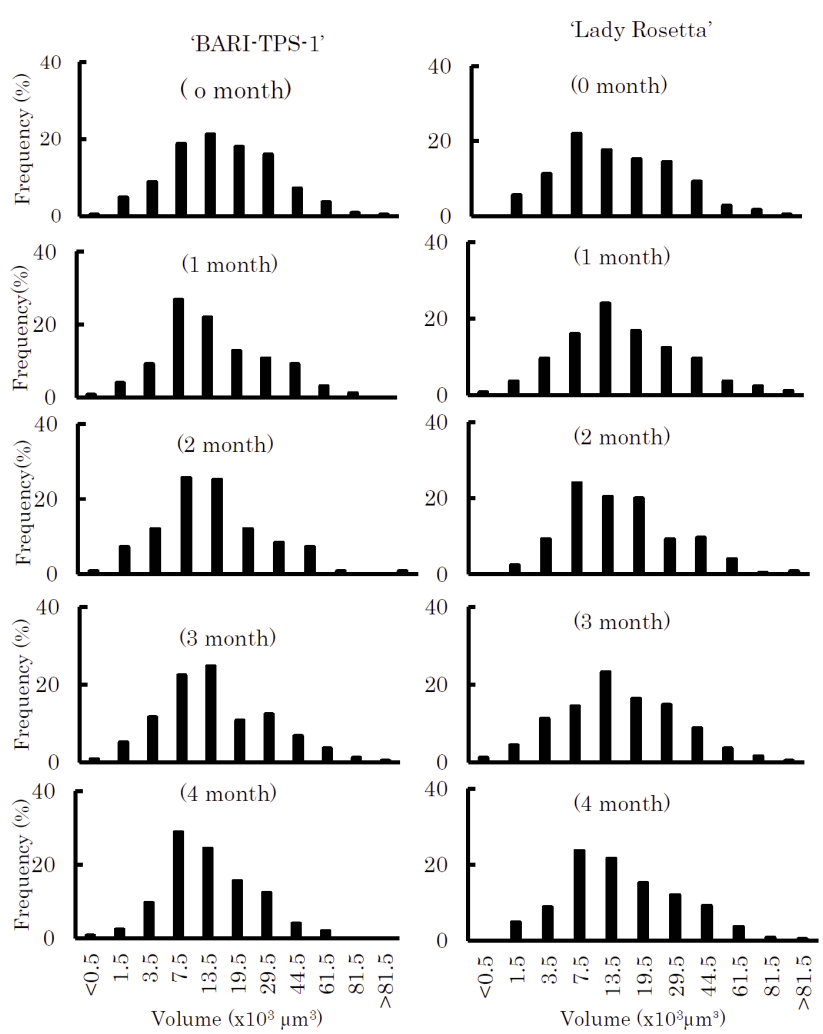

Fig. 3 - Change in histogram for frequency percentage of potato starch granule volume derived from 'BARI-TPS-1' and 'Lady Rosetta' potato varieties as influenced by storage period.
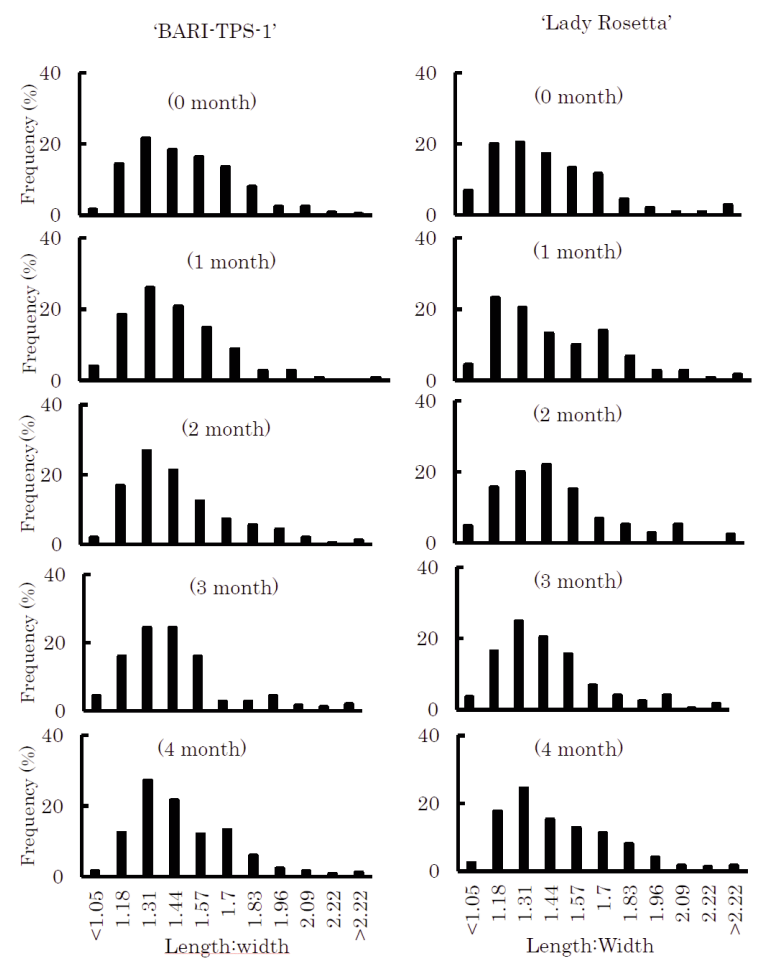

Fig. 4 - Change in histogram for frequency percentage of potato starch granule Length:Width ratio derived from 'BARITPS- 1 ' and 'Lady Rosetta' potato varieties as influenced by storage period. 

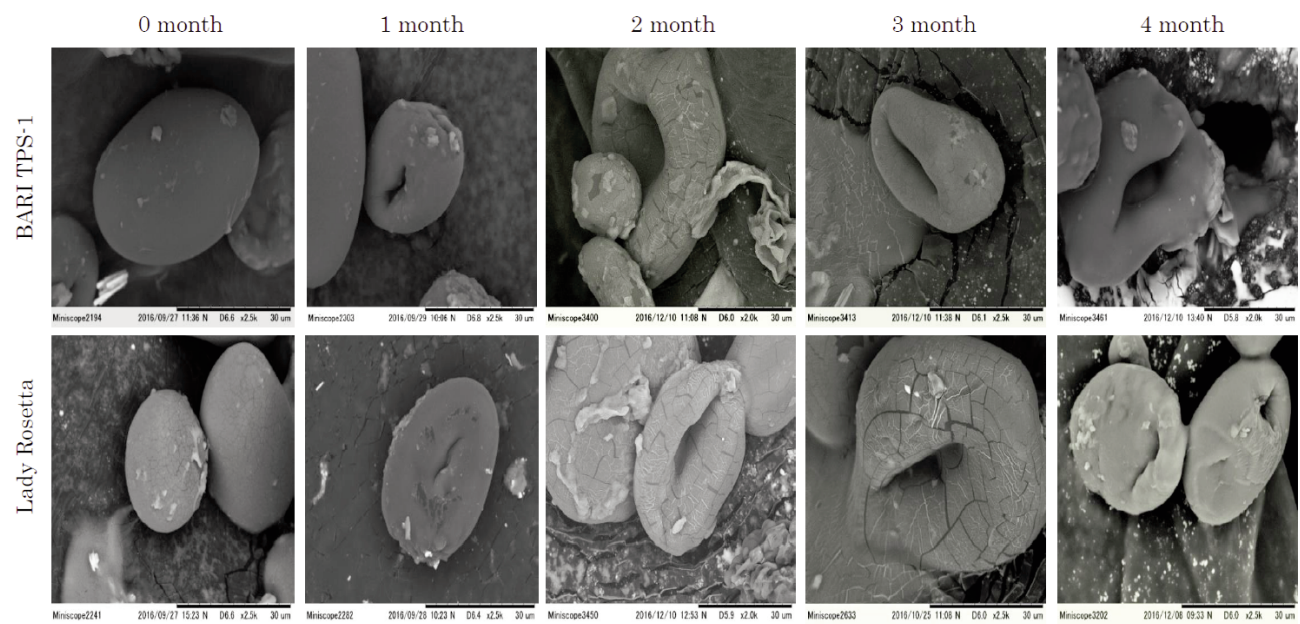

Fig. 5 - Scanning electron micrographs showing the surface morphology of starch granules of 'BARI TPS-1' and 'Lady Rosetta' and potato tuber stored at $5^{\circ} \mathrm{C}$ at 0 to 4 months of storage.

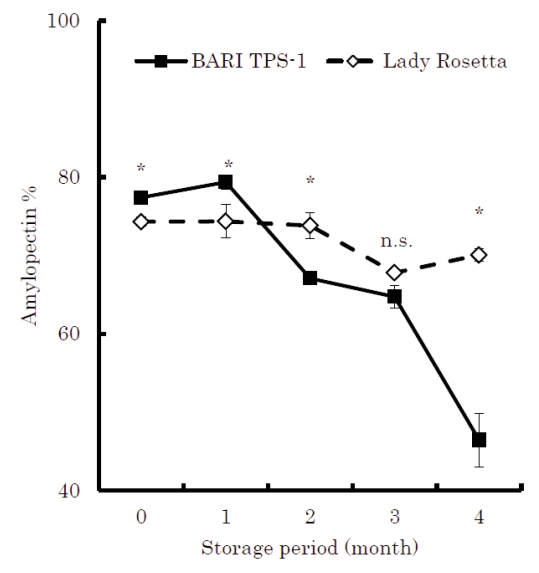

Fig. 6 - Changes in the percentage of amylopectin in 'BARI-TPS-1' and 'Lady Rosetta' potato tubers as influenced by storage period.

\section{Discussion and Conclusions}

In potato tuber, starch is converted to sugar during cold storage (Malone et al., 2006). The starch content of potato tuber decreased markedly during prolonged storage at $4-8^{\circ} \mathrm{C}$ through the process of conversion of starch into sugars (Nourian et al., 2003; Smith et al., 2005). Ohad et al. (1971) also reported reduction of starch content by $26 \%$ after 17 days of storage. Mature dormant potato tuber produced sugars by degradation of a small fraction of starch (Isherwood, 1973). Thus starch content decreased because of the hydrolysis of starch by starch degrading enzymes (Nielsen et al., 1997), suggesting why reducing sugar content increased as starch content decreased during cold storage (Fig. 1). Storage at 0$5{ }^{\circ} \mathrm{C}$ increases sugar accumulation in potato tuber (Wismer et al., 1995; Blenkinsop et al., 2003), which coincides with these experiments where both varieties showed higher reducing sugar content after storage with a significant difference between 'BARI TPS-1' and Lady Rosetta (Fig. 1). This increased level of reducing sugar and decreased level of starch content is related with the increased activity of hydrolysing enzyme (Sowokinos, 2001), which might explain the higher starch degradation in 'BARI TPS-1' (Fig. 1).

During low-temperature storage, the enhancement of sucrose and hexoses (glucose and fructose) levels is known as "cold sweetening' or 'low temperature sweetening', which is an important metabolic process in the roots of many species as well as potato tuber (Wismer et al., 1995; Espen et al., 1999; Galindo et al., 2004; Galindo et al., 2007). The soluble sugar content of potato tuber increases at low temperature such as $4^{\circ} \mathrm{C}$, when stored for 6 to 12 weeks because of starch decomposition and then inclines to decrease (Cochrane et al., 1991; Chen et al., 2012). Total sugar and sucrose content both showed a similar changing pattern after storage with significantly higher content in 'BARI TPS- 1 ' during 2 and 3 months (Fig. 1). Cold storage condition triggers the tuber starch to breakdown into sucrose through various hydrolytic enzymes which further hydrolyzed into reducing sugars (glucose and fructose) (Sowokinos, 2001). The amount of soluble sugar accumulated in 
tuber also depends on different cultivars (Zommick et al., 2014).), which could explain the higher reducing sugar in 'BARI TPS-1' after storage than Lady Rosetta (Santos et al., 2020).

However, there was a sudden increase in starch content between $3^{\text {rd }}$ to $4^{\text {th }}$ months of storage in 'Lady Rosetta' variety (Fig. 1), suggesting recondition of starch or increase of respiration losses during storage. The difference in respiration rates depend on cultivar, growing conditions, experimental conditions, and physiological status of the tubers (Fennir et al., 2003). Comparatively lower starch degradation after 3 to 4 months of storage might have contributed to lower presence of reducing sugar in 'Lady Rosetta' (Fig. 1). This can also be explained that likely the rise of starch content between 3 and 4 months of storage, amylopectin percentage also showed similar kind of tendency in 'Lady Rosetta' variety (Fig. 6). An increase in amylopectin percentage from 3 to 4 months of storage suggested lower enzymatic degradation (Fig. 6) (Hofvander et al., 2004). It seemed amaylase enzyme activity reduced during 3 to 4 months of storage because of sprouting of seed potato varieties or it can be explained that the amaylase enzyme activity was not enough to degrade the starch in seed potato (Lewis et al., 1994). As the experimental condition was same for both of the tubers, hence these may explain faster physiological aging in seed potato variety than TPS variety. This may also suggest that experimental storage temperature might have affected the respiration losses; and the sugar had been used for tuber germination in case of seed tuber (Olsen et al., 2003).

The TPS variety showed higher starch degradation rate than the seed potato (Fig. 1), and sharp decrease in amylopectin percentage after storage (Fig. 6), moreover there was higher percentage of amylopectin degradation in 'BARI TPS- 1 ' than 'Lady Rosetta' starting after 1 month of storage and continued as the storage progressed (Fig. 6), but there was no apparent changes in starch granule volume and ovality (legth:width ratio) (Fig. 2). This result suggested a non-uniform degradation pattern of starch granules in "BARI TPS-1'and 'Lady Rosetta' varieties.

Histograms were also carried out to investigate, if the starch granule deformation primarily started in smaller sized granules, or larger sized granules (Figs. 3 and 4). Singh et al. (2008) reported a shift of granule size range to smaller granule sizes in isolated starches of New Zealand Taewa (Maori potato) when they were stored for three and six months at $4^{\circ} \mathrm{C}$ temperature. This experiment also reported erosion and pitting on the surface of stored potato starch. In case of banana, surface erosion by enzymatic degradation resulted in smaller granules with elongated shape and exo-corrosion process caused pits on the surface of the starch granule with high frequency (Peroni-Okita et al., 2013). This shift of granule size distribution has been related to rapid digestion of starch granule and composition variation between small and large granules (Salunkhe et al., 1989). However, there were no considerable changes of starch granule sizes in both potato cultivars in our study. This suggested that, in spite of having significant change in starch degradation along storage in both variety, it had hardly influenced the size of starch granule (Fig. 2, 3 and 4).

Moreover, it was found that even after 4 months of storage periods, there was no significant change in starch granule sizes in both cultivars, in spite of 'Lady Rosetta' having slightly higher tendency in the value of length, width and volume (Fig. 2). Fajardo et al. (2013) also reported unchanged granule size after storage, which was attributed to the nearly undetectable change in volume of starch granule. Russet Burbank potato tubers also showed similar granular size distribution after storage at $3.9^{\circ} \mathrm{C}$ (Johnston et al., 1968).

SEM observation showed that starch granules from both harvested tubers presented smooth granular surface under SEM without any storage treatment or at 0-month storage (Fig. 5). Although there is argument about the appearance of natural potato starch granular surface, several studies showed smooth granular surface of natural potato starch under microscopic observation. Cottrell et al. (1993) reported smooth granular surface of potato starch of Record and Brodick potato cultivar at harvest. (Sarikaya et al., 2000) also reported smooth granular surface of potato starch before any enzymatic or freezing treatment. As the SEM observation in this experiment showed hole or pit formation on granular surface of both varieties after storage (Fig. 5) (Sarikaya et al., 2000; Noda et al., 2005), it is suggested that the long term storage at low temperature of this experiment lowered the starch content which led to susceptibility to hydrolytic enzyme attack that changes the properties and composition of starch granule (Barichello et al. 1990). The cold storage temperature might have given damage to amyloplast membrane by starch hydrolysis (Ohad et al., 1971), which enhanced membrane permeability through 
starch hydrolysis enzymes, and resulted the formation of cracked region or surface hole on the granule (Sujka and Jamroz, 2010).

However, no apparent change was observed in the ratio of granules and histogram analysis of both potato starch granule, but the SEM observation clearly showed deformation of starch granule forming hole or pit like structures gradually started from 1 month of storage and continued to 4 months of storage (Fig. 5). On the other hand, gradual starch degradation and decreased amylopectin percentage indicated activation of enzymatic degradation in both cultivars after storage (Fig. 1 and 6). Therefore, it is suggested that starch granule erosion may occur at specific surface region of the granule causing no change in the granular size. Starch hydrolyging enzyme like a-amylase might have attacked at particular points on the granule surface, forming tunnels into the granule, thus hydrolyzed the granule from the inside (Lindeboom et. al., 2004). Similar finding was reported by Peroni-Okita et al. (2013) where starch granules of green banana maintained the rounded shape after low temperature but presented pits on the granule surface which was enlarged by the corrosion process, suggesting partial degradation of starch granules.

Thus enzyme molecules can affect the starch granule in different patterns either by forming pin holes, medium sized hole, sponge like erosion or selected point at the surface leading to a single hole (Sujka and Jamroz, 2010). Enzyme can gain access to innermost region of the starch granule by faster digestion than at the periphery region of the granule, which can form shallow hole like structure (Duffus, 1984). This may explain how the both starch granules showed no changes in their sizes despite of granular deformation.

However, 'BARI TPS-1' showed a higher starch degradation percentage throughout the storage period than the seed tuber potato. This suggested higher susceptibility of starch degrading enzyme in TPS tuber than that of seed potato tuber. Variation in starch granule morphology and their crystalline organization may explain the susceptibility to enzymatic degradation (Gallant et al., 1992). Amylase plays the major role in in-vivo breakdown of starch (Manners, 1985). Amylose and amylopectin ratio may explain the degradation pattern of starch granules in both TPS and seed potato varieties. Both the potato tuber showed decreased percentage of amylopectin along the storage period, whereas 'BARI TPS-1' resulted lower amylopectin percentage than the seed potato (Fig. 6). Bach et al. (2013) described that as amylopectin degrades more rapidly than amylose, it causes activation of more starch degrading enzymes. Therefore, 'BARI TPS-1' might have allowed deeper penetration of starch degrading enzymes than the seed tuber in spite of no apparent changes in granule size (Fig. 5). As the extent of pit or cavity of starch granules were not determined in this experiment, it can be suggested that probably a different inner molecular organization of TPS starch granule may be allowed differentiated enzyme attack, which could be responsible for slightly smaller starch granule than 'Lady Rosetta' during Storage (Fig. 6) with no significant difference. This also suggests that starches vary in their resistance to enzymatic susceptibility (Srichuwong et al., 2005).

There are different opinions about the presence of pores or holes on the surface of potato starch granules. Although several observations concluded that some factors could cause an increase in the number and size of pores on starch granules surface (Fannon et al., 1992). Moreover, the expansion of granule degradation increased with the increased enzyme concentration (Mu et al., 2015). During enzymatic hydrolysis, some regions of granules are more susceptible to enzyme attack because of less organized amorphous rings, whereas the crystalline lamella provides higher resistance to enzymatic erosion (Oates, 1997). This kind of enzymatic hydrolysis was characterized by forming a hole by creating channel through the less resistant granule core (Jung et al., 2017), which may explain deeper enzyme penetration in TPS tuber. Action pattern of both endoand exo-amylase at a lower temperature may explain overall amylolytic activity in TPS and seed potato tubers (Shin et al., 2002; Nabubuya et al., 2012).

\section{Conclusions}

In this experiment, the starch content of TPS tuber degraded more rapidly and produced higher reducing sugar content than the seed potato variety after storage. This result indicated that, TPS tuber may not be acceptable for low temperature storage compare to seed potato variety. There were no significant changes in granule size and volume, indicated that granule did not change as a ratio in both tubers. However, both potato granules deformed by forming holes or cavities at innermost surface region 
after storage, suggesting the starch granule degraded partially rather than concentrically. As both the tubers showed a similar kind of degradation pattern of starch granule in spite of higher starch degradation rate in TPS tuber, similarly the rapid degradation rate of amylopectin in TPS tuber explained higher amylase activities in TPS than the seed tuber. This result suggested possibilities of deeper penetration in TPS starch granule than the seed tuber starch granules. Further studies on the susceptibility of starch degrading enzyme on TPS and seed potato can be done to foresee the starch degradation pattern in TPS and seed potato tuber.

\section{Acknowledgements}

The authors thankfully acknowledged the authority of Japan Society for Promotion Science (JSPS) and University Grants Commission (UGC) of Bangladesh for supporting to conduct of the experiment.

\section{References}

ADEJUMO A.L., ADERIBIGBE, OWOLABI R.U., 2013 Comparitive studies of starch susceptibilities to $\alpha$-amylase degradation of different cereal and root crops of Nigeria. - Afr. J. Biotechnol., 12(29): 4663-4669.

ARISTIZABAL J., SANCHEZ T., LORIO D.M., 2007 - Guía técnica para producción y análisis de almidón de yuca: Organización de las Naciones Unidas para la Agricultura y la Alimentación Roma. - ISBN: 92-5305677-0

BACH S., YADA R.Y., BIZIMUNGU B., FAN M., SULLIVAN J.A., 2013 - Genotype by environment Interaction effects on starch content and digestibility in potato (Solanum tuberosum L.). - J. Agric. Food Chem., 61(16): 39413948.

BADENHUIZEN N.P., 1965 - Occurrence and development of starch in plants. - In: WHISTLER R.L., and E.F. PASCHALL (eds.) Starch: Chemistry and technology. Academic Press, New York, pp. 65-104.

BARICHELLO V., YADA R.Y., COFFIN R.H., STANY D.W., 1990 - Low temperature sweetening in susceptible and resistant potatoes: Starch structure and composition. - J. Food Sci., 55(4): 1054-1059.

BIEMELT S., HAJIREZAEI M., HENTSCHEL E., SONNEWALD U., 2000 - Comparative analysis of abscisic acid content and starch degradation during storage of tubers harvested from different potato varieties. - Potato Res., 43(4): 371-382.

BLENKINSOP R.W., COPP L.J., YADA R.Y., MARAGONIA G.,
2003 - A proposed role for the anaerobic pathway during low-temperature sweetening in tubers of Solanum tuberosum. - Physiol. Plant., 118(2): 206-212.

CHEN X., SONG B., LIU J., YAN J., H.E. T., LIN Y., ZHANG, H., XIE C., 2012 - Modulation of gene expression in coldinduced sweetening resistant potao species Solanum berthaultii exposed to low temperature. - Mol. Genet. Genomics., 287: 411-421.

COCHRANE M.P., DUFFUS C.M., ALLISON M.J., MACKAY G.R., 1991 - Amylolytic activity in stored potato tubers. 1. Estimation usingp-nitrophenyloligosaccharides. Potato Res., 34: 325-332.

COTTRELL J.E., DUFFUS C.M., MACKAY G.R., ALLISON M.J., 1993 - Changes in the surface morphology of starch granules of the cultivated potato, Solanum tuberosum L. during storage. - Potato Res., 36: 119-125.

DUFFUS C.M., 1984 - Metabolism of reserve starch. - In: LEWIS D.H. (ed.) Storage carbohydrates in vascular plants. Society for Experimental Biology Seminar Series, pp. 231-252.

ESPEN L., MORGUTTI S., ABRUZZESE A., NEGRINI N., RIVETTA A., QUATTRINI M.M., COCUCCI M., COCUCCI S. M., 1999 - Changes in the potato (Solanum tuberosum L.) tuber at the onset of dormancy and during storage at $23^{\circ} \mathrm{C}$ and $3{ }^{\circ} \mathrm{C}$. I. Biochemical and physiological parameters. - Potato Res., 42(2): 189-201

EZEKIEL R., RANA G., SINGH N., SINGH S., 2010 - Physicochemical and pasting properties of starch from stored potato tubers. - J. Food Sci. Technol., 47(2): 195-201.

FAJARDO D., HAYNES K.G., JANSKY S., 2013 - Starch characteristics of modern and heirloom potato cultivars. Am. J. Potato Res., 90: 460-469.

FANNON J.E., HAUBER R.J., BEMILLER J.N., 1992 - Surface pores of starch granules. - Cereal Chem., 69: 284-288.

FENNIR M.A., LANDRY J.A. RAGHAVAN G.S.V., 2003 Development and testing of an automated infrared gas analysis system for postharvest respiration study. Appl. Eng. Agric., 19(3): 335-340.

FRANCO C.M.L., CIACCO C.F., TAVARES D.Q., 1988 - Studies on the susceptibility of granular Cassava and corn starches to enzymatic attack. Part 2. Study of the granular structure. - Starch., 40(1):29-32.

GALINDO F.G., HERPPICH W., GEKAS V., SIOHOLM I., 2004 Factors affecting quality and postharvest properties of vegetables: integration of water relations and metabolism. - Crit. Rev. Food Sci. Nutr., 44(3): 139-154.

GALINDO F.G., SIOHOLM I., RASMUSSON A.G., WIDELL S., KAACK K., 2007 - Plant stress physiology: opportunities and challenges for the food industry. - Crit. Rev. Food Sci. Nutr., 47(8): 749-763.

GALLANT D.J., BOUCHET B., BULEON A., PEREZ S., 1992 Physical characteristics of starch granules and susceptibility to enzymatic degradation. - Eur. J. Clin. Nutr., 46(2): 3-16.

GUPTA A.K., KAUR N., 2000 - Carbohydrate reserves in plants: synthesis and regulation. - Elsevier, Ludhiana, 
India, pp. 223-248.

HOFVANDER P., ANDERSSON M., LARSSON C.T., LARSSON H., 2004 - Field performance and starch characteristics of high-amylose potatoes obtain, ed by antisense gene targeting of two branching enzymes. - Plant Biotech. J., 2(4): 311-320.

HOOVER R., ZHOU Y., 2003 - In vitro and in vivo hydrolysis of starches by $\alpha$-amylase and resistant starch formatin in legumes - a review. - Carbohydr. Polym., 54(4): 401417.

ISHERWOOD F.A., 1973 - Starch-sugar interconversion in Solanum tuberosum. - Phytochem., 12(11): 2579-2591.

JOHNSTON F., URBAS B. KHANZADA G., 1968 - Effect of storage on the size distribution and amylose/amy, lopectin ratio in potato starch granules. - Amer. Potato J., 45(9): 315-321.

JUNG Y.S., LEE B.H., YOO S.H., 2017 - Physical structure and absorption properties of tailor-made porous starch granules produced by selected amylolytic enzymes. PloS one, 12(7): 1-14.

KARIM M.R., KHAN M.M.H., UDDIN M.S., SANA N.K., NIKKON F., RAHMAN M.H., 2008 - Studies on the sugar accumulation and carbohydrate splitting enzyme levels in post harvested and cold stored potatoes. - J. Biol. Sci., 16: 95-99.

KASEMWONG K., PIYACHOMKWAN K., WANSUKSRI R. SRIROTH K., 2008 - Granule sizes of canna (Canna edulis) starches and their reactivity toward hydration enzyme hydrolysis and chemical substitution. - Starch Stärke, 60(11): 624-633.

KAZAMI D., TSUCHIYA T., KOBAYASHI Y., OGURA N., 2000 Effect of storage temperature on quality of potato tubers. - J. Japanese Soc. Food Sci. Technol., 47(11): 851-856.

KIMURA A., ROBYT J.F., 1995 - Reaction of enzymes with starch granules: kinetics and products of the reaction with glucoamylase. - Carbohydr. Res., 277(1): 87-107.

KONG B.W., KIM J.I., KIM M.J., KIM J.C., 2003 - Porcine pancreatic alpha-amylase hydrolysis of native starch granules as a function of granule surface area. Biotechnol. Prog., 19: 1162-1166.

LEWIS C.E., LANCASTER J.E., MEREDITH P., WALKER J.R.L., 1994 - Starch metabolism during growth and storage of tubers of two New Zealand potato cultivars. - J. Crop Hort. Sci., 22(3): 295-304.

LI J.H., VASANTHAN T., HOOVER R., ROSSNAGEL B.G., 2004 - Starch from hull-less barley: $V$. in-vitro susceptibility of waxy, normal, and high-amylose starches towards hydrolysis by alpha-amylases and amyloglucosidase. Food Chem., 84(4): 621-632.

LINDEBOOM N., CHANG P.R., TYLER R.T., 2004 - Analytical, biochemical and physicochemical aspects of starch granule size, with emphasis on small granule starches: A review. - Starch, 56(34): 89-99.

MALONE J.G., MITTOVA V., RATCLIFFE R.G. KRUGER N.J., 2006 -The response of carbohydrate metabolism in potato tubers to low temperature. - Plant Cell Physiol. 47(9): 1309-1322.

MANNERS D.J., 1985 - Starch, pp. 149-204. - In: DEY P.M., and R.A. DIXON (eds.) Biochemistry of storage carbohydrates in green plants. Academic Press, London, UK, pp. 378.

MU T.-H., ZHANG M., RAAD L., SUN H.-N., WANG C., 2015 Effect of $\alpha$-amylase degradation on physicochemical properties of pre-high hydrostatic pressure-treated potato starch. - PLOS ONE., 10: e0143620.

NABUBUYA A., NAMUTEBI A., BYARUHANGA Y., NARYAHUS J., STENSTROM Y., WICKLUND T., 2012 Amylolytic activity in selected sweetpotato (Ipomoea batatas Lam) varieties during development and in storage. - Food Nutr. Sci., 3(5): 660-668.

NAEEM M., TETLOW I.J., EMES M.J., 1997 - Starch synthesis in amyloplasts purified from developing potato tubers. - Plant J., 11(5): 1095-1103.

NELSON N.A., 1944 - Photometric adaptation of the Somogyi method for the determination of glucose. - J. Biol. Chem., 153: 375-380.

NIELSEN T.H., DEITING U., STITT M., 1997 - A [beta]-amylase in potato tubers is induced by storage at low temperature. - Plant Physiol., 113(2): 503-510.

NODA T., TAKIGAWA S., MATSUURA-ENDO C., KIM S.J., HASHIMOTO N. YAMAGUCHI H., HANASHIRO I., TAKEDA Y., 2005 - Physicochemical properties and amylopectin structures of large, small, and extremely small potato starch granules. - Carbohydr. Polym., 60(2): 245-251.

NODA T., TAKIGAWA S., MATSUURA-ENDO C., SUZUKI T., HASHIMOTO N., KOTTEARACHCHI N.S., ZAHIDUL I.S.M., 2008 - Factors affecting the digestibility of raw and gelatinized potato starches. - Food Chem., 110(2): 465470.

NOURIAN F., RAMASWAMY H.S., KUSHALAPPA A.C., 2003 Kinetics of quality change associated with potatoes stored at different temperatures. - LWT - Food Sci. Technol., 36(1): 49-65.

OATES C.G., 1997 - Towards an understanding of starch granule structure and hydrolysis. - Trends Food Sci. Technol., 8: 375-382.

O'DONOGHUE E.P., YADA R.Y., MARAGONI A.G., 1995 Low temperature sweetening in potato tubers: the role of the amyloplast membrane. - J. Plant Physiol., 145: 335-341.

OHAD I., FRIEDBERG I., NE'EMAN Z. SCHRAMM M., 1971 Biogenesis and degradation of starch: I. The fate of the amyloplast membranes during maturation and storage of potato tubers. - Plant Physiol., 47(4): 465-477.

OLSEN N., THORNTON R.E. BARITELLE A., HYDE G., 2003 The influence of storage conditions on physical and physiological characteristics of Shepody potatoesa. Potato Res., 46(1): 95-103.

PANGARIBUAN D.H., 1994 - The effects of planting depth and hilling upon the growth and yield of potatoes 
grown from true potato seed (TPS). - Acta Horticulturae, 369: 358-367.

PERONI-OKITA F.H.G., CARDOSO M.B., AGOPIAN R.G.D., LOURO R.P., NASCIMENTO J.R.O. PURGATTO E., TAVARES M.I.B., LAJOLO F.M., CORDENUSI B.R., 2013 The cold storage of green bananas affects the starch degradation during ripening at higher temperature. Carbohydr. Polym. 96(1): 137-147.

PINHERO R.G., COPP L.J., AMAYA C.L., MARAGONI A.G., YADA R.Y., 2007 - Roles of alcohol dehydrogenase, lactatedehydrogenase and pyruvate decarboxylase in lowtemperature sweetening in tolerant and susceptible varieties of potato (Solanum tuberosum). - Physiol. Plant., 130(2): 230-239.

PLANCHOT V., COLONNA P., GALLANT D.J., BOUCHET B., 1995 - Extensive degradation of native starch granules by alpha-amylase from Aspergillus fumigatus. - J. Cereal Sci., 21: 163-171.

SALUNKHE D.K., DESAI B.B., CHAYAN J.K., 1989 - Potatoes. - In: ESKIN N.A.M. (ed.) Quality and preservation of vegetables. CRC Press Inc, Boca Raton, Florida, pp. 152.

SANTOS M.N.S., ARAJO F.F., LIMA P.C.C., COSTA L.C., FINGER F.L., 2020 - Changes in potato tuber sugar metabolism in response to natural sprout suppressive compounds. - Acta Sci. Agron., 42: 1-6.

SARIKAYA E., HIGASA T., ADACHI M., MIKAMI B., 2000 Comparison of degradation abilities of $\alpha$ - and 8 -amylases on raw starch granules. - Process Biochem., 35(7): 711-715.

SHIN K.S., CHAKRABARTY D., PAEK K.Y., 2002 Sproutingrate, change of carbohydrate contents and related enzymesduring cold treatment of lily bulblets regenerated in vitro. - Sci. Hortic., 96: 195-204.

SINGH J., COLUSSI R., McCARTHY O.J. KAUR L., 2016 Potato Starch and Its Modification. - In: SINGH J., and L. KAUR (eds.) Advances in potato chemistry and technology. Academic Press, Cambridge, Massachusetts, USA, pp. 195-247.

SINGH J., McCARTHY O.J., SINGH H., MOUGHAN P.J., 2008 - Low temperature post-harvest storage of New Zealand Taewa (Maori potato): Effects on starch physi- co-chemical and functional characteristics. - Food Chem., 106(2): 583-596.

SINGH N., SINGH J., KAUR L., SINGH SODHI N., SINGH GILL B., 2003 - Morphological, thermal and rheological properties of starches from different botanical sources. Food Chem., 81(2): 219-231.

SMITH A.M., ZEEMAN S.C., SMITH S.M., 2005 - Starch degradation. - Annu. Rev. Plant Biol., 56: 73-98.

SOWOKINOS J.R., 2001 - Biochemical and molecular control of cold-induced sweetening in potatoes. - Am. J. Potato Res., 78(3): 221-236.

SRICHUWONG S., SUNARATI T. C., MISHIMA T., ISONO N., HISAMATSU M., 2005 - Starches from different botanical sources II: Contribution of starch structure to swelling and pasting properties. - Carbohydr. Polym., 62(1): 25-34.

SUJKA M., JAMROZ J., 2010 - Characteristics of pores in native and hydrolyzed starch granules. - Starch., 62(5): 229-235.

TESTER R.F., QI X., KARKALAS J., 2006 - Hydrolysis of native starches with amylases. - Anim. Feed Sci. Technol., 130(1-2): 39-54.

WANG J., GUO K., FAN X., FENG G., WEI C., 2018 Physicochemical properties of C-type starch from root tuber of Apios fortunei in comparison with maize, potato, and pea starches. - Molecules, 23(9): 2132.

WISMER W.V., MARAGONI A.G., YADA R.Y., 1995 - Lowtemperature sweetening in roots and tubers. - Hortic. Rev., 17: 203-231.

YAMDEU J.H.G., GUPTA P.H., SHAH A.K., PATEL N.J., TALATI J.G., 2015 - Effect of storage temperature on carbohydrate metabolism and development of cold-induced sweetening in indian potato (Solanum Tuberosum L.) varieties. - J. Food Biochem., 40(1): 71-83.

ZHANG H., HOU J., Liu XIE C., SONG B., 2014 - Amylase analysis in potato starch degradation during cold storage and sprouting. - Potato Res., 57(1): 47-58.

ZOMMICK D.H., KNOWELS L.O., PAVEK M.J., KNOWLES N.R., 2014 - In-season heat stress compromises postharvest quality and low-temperature sweetening resistance in potato (Solanum tuberosum L.). - Planta, 239(6): 1243-1263. 
